\title{
Decrease of the DNA methylation levels of the $A D R B 3$ gene in leukocytes is related with serum folate in eutrophic adults
}

\author{
Yohanna de Oliveira1*, Raquel Patrícia Ataíde Lima', Rafaella Cristhine Pordeus Luna', \\ Mussara Gomes Cavalcanti Alves Monteiro', Cássia Surama Oliveira da Silva', \\ Rayner Anderson Ferreira do Nascimento ${ }^{2}$, Keylha Querino de Farias Lima', Ana Hermínia Andrade e Silva ${ }^{3}$, \\ Flávia Emília Leite de Lima Ferreira' ${ }^{1}$ Rodrigo Pinheiro de Toledo Vianna', Ronei Marcos de Moraes ${ }^{3}$, \\ Naila Francis Paulo de Oliveira ${ }^{4}$, Aléssio Tony Cavalcanti de Almeida ${ }^{5}$, Alexandre Sérgio Silva ${ }^{1}$, \\ Alcides da Silva Diniz ${ }^{6}$, Maria José de Carvalho Costa $^{1}$ and Maria da Conceição Rodrigues Gonçalves ${ }^{1}$
}

\begin{abstract}
Background: DNA methylation has been evidenced as a potential epigenetic mechanism related to various candidate genes to development of obesity. Therefore, the objective of this study was to evaluate the DNA methylation levels of the $A D R B 3$ gene by body mass index (BMI) in a representative adult population, besides characterizing this population as to the lipid profile, oxidative stress and food intake.
\end{abstract}

Methods: This was a cross-sectional population-based study, involving 262 adults aged 20-59 years, of both genders, representative of the East and West regions of the municipality of João Pessoa, Paraíba state, Brazil, in that were evaluated lifestyle variables and performed nutritional, biochemical evaluation and DNA methylation levels of the ADRB3 gene using high resolution melting method. The relationship between the study variables was performed using analyses of variance and multiple regression models. All results were obtained using the software R, 3.3.2.

Results: From the stratification of categories BMI, was observed a difference in the average variables values of age, waist-to-height ratio, waist-to-hip ratio, waist circumference, triglycerides and intake of trans fat, which occurred more frequently between the categories "eutrophic" and "obesity". From the multiple regression analysis in the group of eutrophic adults, it was observed a negative relationship between methylation levels of the ADRB3 gene with serum levels of folic acid. However, no significant relation was observed among lipid profile, oxidative stress and food intake in individuals distributed in the three categories of BMI.

Conclusions: A negative relationship was demonstrated between methylation levels of the ADRB3 gene in eutrophic adults individuals with serum levels of folic acid, as well as with the independent gender of BMI, however, was not observed relation with lipid profile, oxidative stress and variables of food intake. Regarding the absence of relationship with methylation levels of the ADRB3 gene in the categories of overweight, mild and moderate obesity, the answer probably lies in the insufficient amount of body fat to initiate inflammatory processes and oxidative stress with a direct impact on methylation levels, what is differently is found most of the times in exacerbated levels in severe obesity.

Keywords: ADRB3, DNA methylation, Body mass index, Folic acid

\footnotetext{
*Correspondence: yoh_0806@hotmail.com

${ }^{1}$ Health Sciences Center (Centro de Ciências da Saúde), Departament

of Nutrition, Federal University of Paraíba (Universidade Federal da

Paraíba), João Pessoa, Brazil

Full list of author information is available at the end of the article
} 


\section{Background}

Obesity is considered a serious public health problem, affecting $39 \%$ of the world population [1]. The epidemic projection is that by 2025 , more than 2 billion adults are overweight or obese [2].

Multiple biological, behavioural, genetic and epigenetic determinants are contributing to the multifactorial aetiology of obesity, for example, sleep disturbances, potential traits of obesogenic behavior, characterized by excess calorie intake and sedentary lifestyle, peripheral and central regulation of energy balance, adipose tissue and skeletal muscle biology, in addition to changes from the gut microbiota, hormone signalling, reproductive factors, drugs, and intrauterine and epigenetic intergenerational effects [3].

Increasing evidence indicates that epigenetic modifications in adipose tissue may be involved in pathogenesis of metabolic disorders, fat storage, cell remodeling and adipogenesis, emphasizing the involvement of DNA methylation in differentiation of adipocytes and its effect on expression of genes related to obesity [4].

DNA methylation is the most frequent and wellcharacterized epigenetic mark, for playing a key role on regulating gene expression and at molecular phenotype, without any change in the sequence of DNA, it can be altered by environmental expositions and genetic influences [5]. In addition, folate is a water-soluble B vitamin which plays an important role as donor of methyl groups required for proper epigenetic regulation [6].

Another complexity encountered in studying obesity is the marked heterogeneity of obese individuals, through the notable differences in body configuration and in the regional accumulation of body fat in adiposity levels, such as subcutaneous obesity, in which excess subcutaneous fat is found around the hip and thigh areas, and visceral obesity, in which fat is mainly concentrated in the abdominal region, mainly mesenteric adipose tissue. Visceral obesity, also known as the excess of visceral adipose tissue (VAT), tends to be more pernicious in health terms, being a potential factor for cardiovascular risk [7].

Recently, it was demonstrated the modification in methylation levels of candidate genes to development of obesity exhibited a relation excellent in the discrimination of obesity from non-obesity status, thus suggesting that DNA methylation levels in blood leukocytes has great potential for to characterize the obesity phenotype by to identify robust and biologically relevant epigenetic variation related to body mass index (BMI), using an easily accessible and minimally invasive biological material instead of adipose tissue [8].

Interestingly, the beta- 3 adrenergic receptor (ADRB3) is located on chromosome 8 , which contains two exons and 2.252 base pairs, and is known to play a key role in the regulation of lipolysis in white and brown adipose tissues, which provides free fatty acids for thermogenesis, indicating the participation of the $A D R B 3$ gene in the regulation of body weight in humans [9]. However, the role of the DNA methylation of the ADRB3 gene related to the increase of susceptibility to visceral obesity and alter the body fat distribution have not been fully elucidated yet.

In this context, the present study aims to evaluate the methylation levels of the $A D R B 3$ gene by $\mathrm{BMI}$ in a representative adult population, in addition to characterizing this population as to the lipid profile, oxidative stress and food intake.

\section{Methods \\ Study design}

This is a cross-sectional epidemiological study linked to the project titled: "II Cycle of Diagnosis and Intervention of Food and Nutritional Status and the Most Prevalent Non-Communicable Diseases in the Population of the Municipality of João Pessoa/PB" (II Ciclo de Diagnóstico e Intervenção da Situação Alimentar, Nutricional e das Doenças não Transmissíveis mais Prevalentes da População do Município de João Pessoa/PB, II DISANDNT/PB), which was conducted between May 2015 and May 2016.

\section{Ethical issues}

The research protocol of the project mentioned above, to which the present study is linked, was submitted and approved by the Research Ethics Committee of the Health Sciences Center (Centro de Ciências da Saúde, CCS) of the Federal University of Paraíba (Universidade Federal da Paraíba, UFPB), under the Protocol Number 0559/2013, in accordance with the ethical standards for research involving human beings included in Resolution 466 of the December 12, 2012, meeting of the National Health Council/National Research Ethics Committee.

After identifying the residences in randomly selected city blocks located in the East and West areas of the city of João Pessoa, the researchers introduced themselves to the residents, explaining the purpose of the study and requesting their participation. To respect ethical guidelines for research involving humans, the participants residing in the selected households were included in the study only when they had consented to participation by signing the Informed Consent form.

\section{Sampling}

To conduct this population-based study, representative of the East and West regions of the municipality of João Pessoa, a representative sample of the adult group was calculated using information provided by the city hall, such as the city map, number of blocks per neighborhood, and data from the Brazilian Institute of Geography and Statistics (Instituto Brasileiro de Geografia e Estatística, 
IBGE) [10]. In the present study, two regions (East and West) with similar socioeconomic, epidemiological and lifestyle characteristics in relation to the other regions were selected in order to represent the four regions of the municipality.

For the sample calculation, a single multi-level sampling procedure was used. Due to the presence of heterogeneity in income and the relationship between income, disease prevalence and nutrition [11], stratified sampling was used [12] with the city blocks at the first level. In this level, the neighborhoods/city blocks of the East and West zones of the municipality were ranked by income class into four strata according to information obtained from the IBGE [10].

After stratification, the sample size, or number of representative city blocks per zone, was calculated. Next, the weight of each stratum was calculated as the number of city blocks per zone according by strata, according to the formula defined by Silva, Moraes and Costa [13].

Considering that the average income of adults in the East and West areas was $\mathrm{R} \$ 2213.26$ [data obtained from "The first cycle of diagnoses and intervention of the food and nutritional situation, and of the most prevalent communicable diseases of the municipal population of João Pessoa/PB" (07/2008-01/2010)], with a standard deviation of $R \$ 2601.93$ and a margin of error of $R \$ 3320.00$ in income, the minimum sample of adults in João Pessoa necessary to be statistically representative of the eastern and western areas (with a confidence level of 95\%) was 236 adults. Thus, a sample of 262 adults distributed across the study area was selected.

This study had the following inclusion criteria: individuals aged $20-59$ years; different socioeconomic conditions, and medication users and non-users, with the exception of the drugs described below. Exclusion criteria included the following: individuals with neuropsychiatric disorders; multivitamin, mineral, anorexigen, and anabolic supplement users; and pregnant and lactating women.

\section{Data collection}

The household visits and application of the questionnaires were conducted by graduate students of the Nutrition Programs. These are Master's and doctoral students in the Post Graduate Program in Nutrition Sciences (Programa de Pós Graduação em Ciências da Nutrição, PPGCN) at UFPB who were trained before initiating data collection after the pilot study was conducted. Questionnaires were applied for demographic, socioeconomic, and epidemiological characterization, lifestyle, nutritional and food intake assessment, and also biochemical evaluation.

\section{Nutritional assessment}

Weight and height measurements were taken in triplicate, and the average of the three values was used. The
BMI was then calculated using the body weight $(\mathrm{kg})$ divided by the squared body height (meters), and the cut-off points recommended in adults aged 20-59 years old by the World Health Organization (WHO) were used [14].

Waist circumference (WC) was used to determine abdominal obesity, proceeding the American Heart Association (AHA) cut-off points of $\geq 88 \mathrm{~cm}$ in women and $\geq 102 \mathrm{~cm}$ in men [15]. The waist-hip ratio (WHR) was used to define the abdominal obesity status, defined as a WHR $>0.90$ in men and $>0.85$ in women [16].

The waist-to-height ratio (WHtR) was based on the quotient of the waist and height measurements in centimeters. The cut-off point used was 0.5 , as supported by studies conducted around the world in diverse population as an evaluation tool to identify health risks and related morbidities [17].

\section{Dietary assessment}

To evaluate the regular food intake of the individuals, three 24-h dietary recalls (24HR) were performed, contemplating one at the weekend, with a 15-day interval from the beginning of the data collection, according to a study previously published [18].

\section{Biochemical analysis}

The blood samples were collected from the individuals after a 12-h fasting at home by an experienced nurse, and the analysis of biochemical variables were performed according to a study previously published [18]. The analysis of alpha-1 acid glycoprotein (AGP) was measured using the immunoturbidimetry technique and tests were performed in an automated analyzer (LabMax 240, Labtest, Lagoa Santa, MG, Brazil) using standardized kit following the instructions provided by the manufacturer (Labtest, Lagoa Santa, MG, Brazil).

The Access Folate assay is a paramagnetic particle, chemiluminescent immunoassay for the quantitative determination of folic acid levels in human serum and plasma (heparin) or red blood cells (RBC) using the Access Immunoassay Systems. Folate levels in serum and plasma or RBC are used to assess folate status. The serum folate level is an indicator of recent folate intake, while that a low $\mathrm{RBC}$ folate value can indicate a prolonged folate deficiency. Thus, serum levels of folate were estimated using commercial kit (Access Folate Kit [A98032]; Beckman Coulter, Fullerton, CA, USA). Folate levels were determined by a corpuscle immune chemiluminescence assay (Access 2 Immunoassay System; Beckman Coulter, Fullerton, CA, USA). The assay was performed in accordance with the manufacturers' protocol. Folate deficiency was defined as $<3.10 \mathrm{ng} / \mathrm{ml}$ with analytical sensitivity of $0.5 \mathrm{ng} / \mathrm{ml}$. 


\section{Analysis of DNA methylation levels}

The leukocyte DNA was isolated, quantified and transformed with sodium bisulfite according to the conditions described in a previously published study [18].
To identify the existence of statistically significant relationships between DNA methylation levels of the ADRB3 gene and variables of this study, the following multiple linear regression models were used:

Model 1:

Methylation levels $=\beta 0+\beta 1 *$ Total cholesterol $+\beta 2 * \mathrm{LDL}+\beta 3 * \mathrm{HDL}$

$+\beta 4 *$ Triglycerides $+\beta 5 *$ Homocysteine $+\beta 6 *$ TAC $+\beta 7 *$ MDA

$+\beta 8 *$ Alpha- 1 acid glycoprotein $+\beta 9 *$ Folic acid $+\beta 10 *$ Vitamin B12.

Model 2:

$$
\begin{aligned}
\text { Methylation levels }= & \beta 0+\beta 1 * \text { Calories }+\beta 2 * \text { Total fat }+\beta 3 * \text { Folate } \\
& +\beta 4 * \text { Vitamin } \mathrm{B} 12+\beta 5 * \text { Monounsaturated fat }+\beta 6 * \text { Oleic acid } \\
& +\beta 7 * \text { Omega } 3+\beta 8 * \text { Omega } 6+\beta 9 * \text { Saturated fat }+\beta 10 * \text { Cholesterol } \\
& +\beta 11 * \text { Polyunsaturated fat }+\beta 12 * \text { Trans fat. }
\end{aligned}
$$

The analysis of methylation levels in genomic DNA from blood was performed by High Resolution Melting (HRM) Real Time PCR method in a applied biosystems 7500 fast system. PCR was performed in a total volume of $20 \mu$ l containing: $1 \times$ buffer, $4 \mathrm{mM} \mathrm{Mg}^{2+}, 200 \mu \mathrm{M}$ of each dNTPs (Qiagen), $250 \mathrm{nM}$ of each primer, $5 \mu \mathrm{M}$ SYTO $^{\circledR}$ (Invitrogen), 1 U HotstarTaq DNA Polymerase (Qiagen) and $1 \mu \mathrm{l}$ of bisulfite-modified DNA. Primers were designed from the genome sequence deposited in the UCSC genome browser http://genome-euro.ucsc. edu/(chr8:37,962,991-37,966,965), F:5'-TAGGTGATT TGGGAGATTTTTTTT- $3^{\prime}$ and R:5'-CCCCTAACA ACCCACTAATATTAAC- $3^{\prime}$. The PCR program consisted of an initial enzymatic activation at $95{ }^{\circ} \mathrm{C}$ for $10 \mathrm{~min}$, followed by 50 cycles of $45 \mathrm{~s}$ at $95{ }^{\circ} \mathrm{C}, 45 \mathrm{~s}$ at $60{ }^{\circ} \mathrm{C}$ and $45 \mathrm{~s}$ at $72{ }^{\circ} \mathrm{C}$ and the final extension at $72{ }^{\circ} \mathrm{C}$ for $10 \mathrm{~min}$. The melting curves were normalized by calculation of the 'line of best fit' in between two normalization regions before and after the major fluorescence decrease representing the melting of the PCR product using the software provided with the HRM Software v2.0, provided by 7500 fast system.

\section{Statistical analysis}

All statistical analyses were performed with R software, 3.3.2 [19]. Initially it was performed the characterization of the sample by descriptive statistics represented by a single frequency, using position measurements, such as central tendency and dispersion. The data were tested for normality using Lilliefors test, which is a derivative of the Kolmogorov-Smirnov test. Moreover, analysis of variance (ANOVA) was used to verify if there was a mean difference between the BMI in which subjects were classified, for all quantitative variables of the study.
Considering $5 \%$ as significance.

\section{Results}

The sample comprised 262 adults individuals, being 175 female $(66.79 \%)$ and 87 males (33.21\%).

In Table 1, it was performed the multiple comparison testing of means for each variable, through the ANOVA test, it was observed a difference in mean variables values described below, in relation to nutritional status: average age, waist-to-height ratio (WHtR), waist-to-hip ratio (WHR), waist circumference (WC), triglycerides and intake of trans fat. It is relevant to mention that methylation levels did not differ significantly by nutritional status.

To know which of BMI categories there was a significant difference, Tukey's test was performed, which occurred more frequently between the categories "eutrophic" and "obesity".

No significant association was observed among the variables methylation levels of $A D R B 3$ gene with lipid profile and oxidative stress in nutritional status of eutrophic, overweight or obesity. However, it was observed that methylation levels of $A D R B 3$ gene were negatively associated with serum levels of folic acid in the eutrophic adults group; when folic acid values increased by $1 \mathrm{ng} / \mathrm{ml}$, methylation levels decreased in mean, $2.27 \%$ ( $\mathrm{p}$-value $=0.0327<0.05$ ), according showed in Table 2. When applied multiple regression based on model 1 including age and gender factors in the three categories of BMI observed that there was only relationship for methylation levels and male gender in eutrophics (Additional file 1). This result means that, on average, eutrophics males have 0.1527 more methylation levels than females ( $\mathrm{p}$-value $=0.0070<0.05$ ).

Regarding the results of multiple regression based on model 2 described previously ont food intake, was not 
Table 1 Characteristics of adults population by nutritional status of the municipality of João Pessoa/PB/Brazil

\begin{tabular}{|c|c|c|c|c|}
\hline Parameter & Eutrophic (43.51\%) & Overweight (36.26\%) & Obesity (20.23\%) & $p$-value \\
\hline $\begin{array}{l}\text { Methylation levels (\%) } \\
\text { Mean } \pm \text { SD }\end{array}$ & $43.29 \pm 19.14$ & $39.32 \pm 17.57$ & $42.74 \pm 17.29$ & 0.6020 \\
\hline $\begin{array}{l}\text { Average age } \\
\text { Mean } \pm S D\end{array}$ & $35.07 \pm 11.83^{\mathrm{ab}}$ & $41.78 \pm 12.52^{b}$ & $42.23 \pm 11.58^{\mathrm{a}}$ & $0.0002^{*}$ \\
\hline $\begin{array}{l}\text { WHtR }(\mathrm{cm} / \mathrm{cm}) \\
\text { Mean } \pm \text { SD }\end{array}$ & $0.40 \pm 0.16^{\mathrm{ab}}$ & $0.55 \pm 0.06^{\mathrm{bc}}$ & $0.61 \pm 0.15^{\text {ac }}$ & $>0.0000^{*}$ \\
\hline $\begin{array}{l}\text { WHR }(\mathrm{cm} / \mathrm{cm}) \\
\text { Mean } \pm S D\end{array}$ & $0.79 \pm 0.08^{\mathrm{ab}}$ & $0.87 \pm 0.09^{b}$ & $0.92 \pm 0.09^{\mathrm{a}}$ & $>0.0000^{*}$ \\
\hline $\begin{array}{l}W C(\mathrm{~cm}) \\
\text { Mean } \pm S D\end{array}$ & $74.45 \pm 9.45^{\mathrm{ab}}$ & $89.48 \pm 8.67^{\mathrm{bc}}$ & $101.52 \pm 13.90^{\mathrm{ac}}$ & $>0.0000^{*}$ \\
\hline $\begin{array}{l}\text { Total cholesterol (mg/dl) } \\
\text { Mean } \pm \text { SD }\end{array}$ & $175.15 \pm 35.63$ & $195.73 \pm 45.19$ & $199.40 \pm 43.48$ & 0.9460 \\
\hline $\begin{array}{l}\mathrm{LDL}(\mathrm{mg} / \mathrm{dl}) \\
\text { Mean } \pm \mathrm{SD}\end{array}$ & $97.74 \pm 47.71$ & $112.03 \pm 56.16$ & $112.54 \pm 62.30$ & 0.1050 \\
\hline $\begin{array}{l}\mathrm{HDL}(\mathrm{mg} / \mathrm{dl}) \\
\text { Mean } \pm \mathrm{SD}\end{array}$ & $45.84 \pm 11.70$ & $41.45 \pm 10.46$ & $42.87 \pm 10.31$ & 0.2740 \\
\hline $\begin{array}{l}\text { Triglycerides (mg/dl) } \\
\text { Mean } \pm S D\end{array}$ & $120.39 \pm 63.78^{a}$ & $158.10 \pm 93.39$ & $158.33 \pm 73.90^{\mathrm{a}}$ & $0.0241^{*}$ \\
\hline $\begin{array}{l}\text { TAC (\%) } \\
\text { Mean } \pm \text { SD }\end{array}$ & $41 \pm 15$ & $41 \pm 14$ & $42 \pm 15$ & 0.6880 \\
\hline $\begin{array}{l}\text { MDA } \\
\text { Mean } \pm S D\end{array}$ & $2.75 \pm 0.99$ & $2.98 \pm 0.89$ & $2.93 \pm 0.75$ & 0.6330 \\
\hline $\begin{array}{l}\text { Alpha-1 acid glycoprotein (mg/dl) } \\
\text { Mean } \pm \text { SD }\end{array}$ & $63.96 \pm 20.86$ & $64.66 \pm 17.67$ & $68.02 \pm 16.45$ & 0.2020 \\
\hline $\begin{array}{l}\text { Homocysteine (micromol/l) } \\
\text { Mean } \pm \text { SD }\end{array}$ & $11.42 \pm 12.40$ & $10.31 \pm 6.43$ & $10.69 \pm 6.25$ & 0.3540 \\
\hline $\begin{array}{l}\text { Serum folate (ng/ml) } \\
\text { Mean } \pm \text { SD }\end{array}$ & $14.23 \pm 5.47$ & $13.67 \pm 4.87$ & $14.70 \pm 5.74$ & 0.5660 \\
\hline $\begin{array}{l}\text { Vitamin B12 (pg/ml) } \\
\text { Mean } \pm \text { SD }\end{array}$ & $277.67 \pm 136.74$ & $261.83 \pm 113.45$ & $289.23 \pm 126.91$ & 0.0936 \\
\hline $\begin{array}{l}\text { Total fat }(\mathrm{g}) \\
\text { Mean } \pm \text { SD }\end{array}$ & $55.12 \pm 29.94$ & $58.85 \pm 52.14$ & $58.47 \pm 46.68$ & 0.8810 \\
\hline $\begin{array}{l}\text { Calories (Kcal) } \\
\text { Mean } \pm S D\end{array}$ & $1805.16 \pm 695.07$ & $1829.67 \pm 1012.35$ & $1954.71 \pm 1815.64$ & 0.7160 \\
\hline $\begin{array}{l}\text { Dietary folate (mcg) } \\
\text { Mean } \pm S D\end{array}$ & $170.58 \pm 174.83$ & $139.58 \pm 111.68$ & $126.53 \pm 89.34$ & 0.5640 \\
\hline $\begin{array}{l}\text { Vitamin B12 (mcg) } \\
\text { Mean } \pm \text { SD }\end{array}$ & $2.10 \pm 1.53$ & $1.86 \pm 1.59$ & $2.01 \pm 1.64$ & 0.1370 \\
\hline $\begin{array}{l}\text { Monounsaturated fat (g) } \\
\text { Mean } \pm \text { SD }\end{array}$ & $14.50 \pm 8.46$ & $16.43 \pm 13.80$ & $15.07 \pm 11.68$ & 0.9240 \\
\hline $\begin{array}{l}\text { Oleic acid }(\mathrm{g}) \\
\text { Mean } \pm \mathrm{SD}\end{array}$ & $9.59 \pm 7.33$ & $12.03 \pm 12.19$ & $11.09 \pm 10.75$ & 0.7780 \\
\hline $\begin{array}{l}\text { Omega } 3(\mathrm{~g}) \\
\text { Mean } \pm \mathrm{SD}\end{array}$ & $0.64 \pm 0.95$ & $0.61 \pm 0.63$ & $0.68 \pm 0.89$ & 0.4100 \\
\hline $\begin{array}{l}\text { Omega } 6(\mathrm{~g}) \\
\text { Mean } \pm \text { SD }\end{array}$ & $5.81 \pm 4.96$ & $6.81 \pm 5.64$ & $8.44 \pm 14.17$ & 0.2660 \\
\hline $\begin{array}{l}\text { Saturated fat (g) } \\
\text { Mean } \pm \text { SD }\end{array}$ & $17.33 \pm 10.69$ & $18.42 \pm 17.72$ & $16.85 \pm 13.36$ & 0.6750 \\
\hline $\begin{array}{l}\text { Cholesterol (mg) } \\
\text { Mean } \pm \text { SD }\end{array}$ & $264.93 \pm 264.93$ & $258.18 \pm 224.64$ & $226.09 \pm 171.47$ & 0.9460 \\
\hline $\begin{array}{l}\text { Trans fat (g) } \\
\text { Mean } \pm S D\end{array}$ & $0.75 \pm 1.60^{\mathrm{a}}$ & $0.61 \pm 0.54$ & $0.76 \pm 0.91^{\mathrm{a}}$ & $0.0172^{*}$ \\
\hline
\end{tabular}

a Significant difference in mean values of the variable between obese and eutrophic individuals ( $p$-value Tukey's test $<0.05$ )

b Significant difference in mean values of the variable between overweight and eutrophic individuals ( $p$-value Tukey's test $<0.05$ )

c Significant difference in mean values of the variable between obese and overweight individuals ( $p$-value Tukey's test $<0.05$ ) 
Table 2 Multiple regression analysis of methylation levels of the ADRB3 gene with lipid profile and oxidative stress of adult individuals by nutritional status

\begin{tabular}{|c|c|c|c|c|}
\hline & Coefficient & $\mathrm{Cl} 95 \%$ & Statistics t & p-value \\
\hline \multicolumn{5}{|c|}{ Total cholesterol (mg/dl) } \\
\hline Eutrophic* & 0.23 & $(-0.10 \pm 0.56)$ & 0.69 & 0.4999 \\
\hline Overweight & 0.06 & $(-0.04 \pm 0.15)$ & 0.61 & 0.5442 \\
\hline Obesity & -0.13 & $(-0.24 \pm-0.01)$ & -1.06 & 0.3000 \\
\hline \multicolumn{5}{|l|}{$\mathrm{LDL}(\mathrm{mg} / \mathrm{dl})$} \\
\hline Eutrophic* & -0.47 & $(-0.82 \pm-0.11)$ & -1.31 & 0.2051 \\
\hline Overweight & -0.02 & $(-0.09 \pm 0.04)$ & -0.38 & 0.7087 \\
\hline Obesity & 0.12 & $(0.03 \pm 0.21)$ & 1.35 & 0.1910 \\
\hline \multicolumn{5}{|l|}{$\mathrm{HDL}(\mathrm{mg} / \mathrm{dl})$} \\
\hline Eutrophic* & 0.41 & $(-0.16 \pm 0.97)$ & 0.72 & 0.4808 \\
\hline Overweight & 0.27 & $(-0.02 \pm 0.56)$ & 0.92 & 0.3639 \\
\hline Obesity & 0.06 & $(-0.49 \pm 0.60)$ & 0.12 & 0.9160 \\
\hline \multicolumn{5}{|c|}{ Triglycerides (mg/dl) } \\
\hline Eutrophic* & 0.08 & $(-0.06 \pm 0.22)$ & 0.54 & 0.5941 \\
\hline Overweight & 0.02 & $(-0.01 \pm 0.05)$ & 0.57 & 0.5742 \\
\hline Obesity & 0.02 & $(-0.04 \pm 0.08)$ & 0.36 & 0.720 \\
\hline \multicolumn{5}{|l|}{ TAC (\%) } \\
\hline Eutrophic ${ }^{*}$ & 27.64 & $(-8.54 \pm 63.83)$ & 0.76 & 0.4543 \\
\hline Overweight & 11.30 & $(-8.87 \pm 31.48)$ & 0.56 & 0.5789 \\
\hline Obesity & 17.42 & $(-7.63 \pm 42.47)$ & 0.70 & 0.4940 \\
\hline \multicolumn{5}{|l|}{ MDA } \\
\hline Eutrophic* & -4.55 & $(-1.37 \pm 10.48)$ & 0.77 & 0.4516 \\
\hline Overweight & -8.07 & $(-12.60 \pm-3.53)$ & -1.78 & 0.0839 \\
\hline Obesity & -1.54 & $(-6.81 \pm 3.72)$ & -0.29 & 0.7720 \\
\hline \multicolumn{5}{|c|}{ Alpha-1 acid glycoprotein (mg/dl) } \\
\hline Eutrophic* & 0.23 & $(0.02 \pm 0.44)$ & 1.07 & 0.2964 \\
\hline Overweight & 0.00 & $(-0.18 \pm 0.19)$ & 0.02 & 0.9880 \\
\hline Obesity & 0.08 & $(-0.16 \pm 0.32)$ & 0.33 & 0.7420 \\
\hline \multicolumn{5}{|c|}{ Homocysteine (micromol/l) } \\
\hline Eutrophic* & -1.74 & $(-3.50 \pm 0.01)$ & -0.99 & 0.3339 \\
\hline Overweight & -0.45 & $(-0.82 \pm-0.08)$ & -1.20 & 0.2368 \\
\hline Obesity & -0.54 & $(-1.02 \pm-0.06)$ & -1.12 & 0.2750 \\
\hline \multicolumn{5}{|c|}{ Serum folate (ng/ml) } \\
\hline Eutrophic* & -2.27 & $(-3.26 \pm-1.28)$ & -2.30 & $0.0327^{*}$ \\
\hline Overweight & -0.79 & $(-1.53 \pm-0.05)$ & -1.06 & 0.2956 \\
\hline Obesity & -0.44 & $(-1.13 \pm 0.25)$ & -0.63 & 0.5330 \\
\hline \multicolumn{5}{|c|}{$V_{i t a m i n} B_{12}(p g / m l)$} \\
\hline Eutrophic* & 6.65 & $(2.72 \pm 10.58)$ & 1.69 & 0.1067 \\
\hline Overweight & 3.67 & $(1.21 \pm 6.14)$ & 1.49 & 0.1452 \\
\hline Obesity & -0.32 & $(-2.80 \pm 2.16)$ & -0.13 & 0.8970 \\
\hline
\end{tabular}

* Eutrophic: after adjustment for sex and age significant relationships remained for methylation levels and male gender

observed significative relationship between methylation levels of $A D R B 3$ gene and food intake in the three categories of $B M I$ (Additional file 1).

\section{Discussion}

In the present study, it was observed that methylation levels of $A D R B 3$ gene were negatively associated with serum levels of folic acid in adult eutrophic individuals. Noting that as serum levels of folic acid in eutrophic individuals increases, methylation levels decreases. However, no significant relationship was observed among lipid profile, oxidative stress and food intake in individuals distributed in the three categories of BMI.

Although the mechanism responsible have not been elucidated yet, higher serum folic acid concentrations were associated with lower DNA methylation levels of $A D R B 3$ gene in eutrophic individuals, which may represent a protective effect for obesity. This finding in accordance with the results of a study that demonstrated that higher serum folic acid concentrations is associated with lower levels of DNA methylation in leukocytes in women with normal weight, and with a distinctive epigenetic response in women with obesity, providing novel evidences that the adequate folate metabolism may be affected by obesity, due probably to the volumetric dilution, resulting in a redistribution of the vitamin from circulation into tissue [6].

Considering the difference between the forms and bioavailability of folates, the folate family of compounds include folic acid and its derivatives which include 5methyltetrahydrofolate (5-MTHF), 5-formyltetrahydrofolate (5-FTHF or folinic acid), 10-formyl-THF, 5,10-methylene-THF and unsubstituted THF. Folic acid, a synthetic oxidized form of folate, is used in supplements and added to food because of its high stability and bioavailability. Folinic acid is a 5-formyl derivative of THF. Unlike the synthetic folate, folinic acid is naturally found in food. It is readily converted to THF without requiring the action of the enzyme dihydrofolate reductase (DHFR). Therefore its function as a vitamin is unaffected by drugs inhibiting this enzyme, such as methotrexate. 5 -MTHF is a biologically active form of folate and is the most abundant form found in plasma, representing $>90 \%$ of folate and is the predominant active metabolite of ingested folic acid [20].

Given the paucity of research on the different BMI categories relating methylation levels in leukocytes in adults of the same population, this study represents the first effort on searching for differences in methylation levels of the $A D R B 3$ gene in varying degrees of obesity, which may help to understand of relations with different categories of the BMI variable.

While it is well-known that central to the pathophysiology of obesity is an excess amount of adiposity, on BMI (which does not directly estimate body fat) still prevails as the most used indicator of adiposity worldwide, for practical reasons, comparability and ease to measure 
weight and height [7]. To refine risk assessment, BMI could be complemented by also measuring WC to discriminate between subcutaneous obesity and visceral obesity, the ratio of WHR circumferences and the WHtR, this latter being a clinical indicator supporting of health risk, revealing that the accumulation of VAT and abdominal subcutaneous fat is strongly associated with cardiometabolic risk [21].

Obesity is a heterogeneous disease with many different subtypes and DNA methylation might contribute to these differences [22]. Although few researchers have investigated the relationship of the ADRB3 gene and its role in susceptibility to obesity, only three studies on methylation were found in the literature consulted, being the first performed with methylation of $A D R B 3$ gene in severely obese men [23], the second with methylation in VAT in obese and slim individuals [9], and the third with methylation in overweight and obese adult women [18].

In this context, Guay et al. [23] demonstrated that higher DNA methylation levels of $A D R B 3$ gene in blood were significantly associated with a lower WHR and lower LDL cholesterol levels in severely obese men. Besides that, $A D R B 3$ g. $-843 \mathrm{C}>\mathrm{T}$ and p.W64R polymorphisms were found to be strongly associated with $A D R B 3$ DNA methylation, reinforcing the impact of both, mutations as well as DNA methylation at the $A D R B 3$ gene promoter.

It has also been postulated that the Trp64Arg ADRB3 genetic variant is associated with 3.9 increase in BMI, and these associations were observed mainly in East Asian populations. In contrast, lower gene expression of the $A D R B 3$ gene in Caucasians and its relationship with higher propensity to obesity and related comorbidities are still controversial [24].

It was reported that the decrease in expression of $A D R B 3$ gene in VAT is associated with obesity, but not with the hypermethylation, demonstrating that the average levels of methylation of this gene in VAT was similar in slim individuals and with obesity from grade III [9], corroborating with the present study regarding the absence of difference of the methylation levels of the $A D R B 3$ gene in leukocytes for different categories of BMI. Thus, the identification in blood such as biomarker easily accessible of the DNA methylation instead of adipose tissue is a promising alternative in the epigenetics field, but still challenging.

However, these findings do not apply to the present study, un precedented regarding methylation levels of the $A D R B 3$ gene in leukocytes in a representative adult population of both genders by BMI categories. As it does not exist in literature searching studies classifying the population based in the three categories of BMI and methylation levels of the ADRB3 gene for comparative purposes, it is suggested that probably other factors have influenced the results such as sample size and non-stratification by gender. It is also important to mention that different blood cell populations may present different methylation profiles, as already shown for genes implicated in immune-related disorders [25], however we do not know if this is applicable to the $A D R B 3$ gene.

Nevertheless, when the gender was analyzed isolated in relation to the methylation profile of ADRB3 gene, it was observed that males showed higher methylation levels than female $(46.40 \pm 18.81$ and $39.42 \pm 17.54$ respectively, $\mathrm{p}=0.0037$; Mann-Whitney). On the other hand, when it evaluated the difference between levels of methylation by age groups no significant results were found (20-39 years old: 42.04 $\pm 19.12,40-59$ years old: $41.40 \pm 17.27 ; \mathrm{p}=0.9310$; Mann-Whitney); (20-30 years old: $39.95 \pm 18.63, \quad 31-40$ years old: $45.70 \pm 19.60$, 41-50 years old: $44.39 \pm 17.28, \quad 51-59$ years old: $39.10 \pm 17.04 ; \mathrm{p}=0.1338$; Kruskal-Wallis). Indeed, the literature shows that in spite of external factors such as diet [18], smoking [26], alcohol consumption [27] and air pollution [28], inner factors such as age and gender have also influence on the DNA methylation profile. Differences in the profile of DNA methylation between males and female have already been observed in skin for $m i R$ 137 gene [29] and in buccal cells for MMP9 and TIMP1 genes [30]. It is noteworthy that sex hormones may regulate DNA methylation differentially in the context of different tissues, developmental stages, and pathological conditions [31].

On the other hand, it is relevant to mention that it was not detectable a relation between the methylation levels of the $A D R B 3$ gene with overweight and obesity, since some studies have shown that these relations are more prominent in severe obesity (grade III e IV) [9, 23]. Suggesting that, in overweight, mild and moderate obesity (grade I e II), the state in which starts triggers the inflammatory cascade and the impacts of oxidative stress, the amount of adiposity is still insufficient to influence the epigenetic marks and result in alterations in phenotype.

Interestingly, DNA methylation, especially in promoter regions, is a well-characterized epigenetic marker related to gene expression regulation in eukaryotes. Usually, methylation levels in the promoter are inversely correlated with the expression levels of the corresponding genes. However, new studies have evaluated the role of DNA methylation in the first exon, revealing that exon methylation facilitates the transcriptional process, and impacts directly in genes expression [32]. Thus, it is understood that other regions of the gene, spite of promoter region, might act in the expression control with different methylation patterns. 
In this context, some issues on the molecular level should be considered. Firstly, methylation may not be the chief mechanism involved in the regulation of activity of that gene in blood. Secondly, the analyzed regions, although carefully chosen, may not be crucial for the regulation of gene expression [9]. Thus, the impact of the methylation levels on $A D R B 3$ gene and its relationship with lipid profile variables and oxidative stress might be better elucidated through further studies of gene expression.

In summary the beta-adrenergic receptor 3 encoded by the $A D R B 3$ gene is involved in the regulation of lipolysis and thermogenesis mainly in adipose tissue which provides free fatty acids for thermogenesis, indicating the participation of the $A D R B 3$ gene in the regulation of body weight in humans. In the present study we analysed blood tissue and it is important to mention that blood is metabolically active tissue, with an important role in the adverse inflammatory and vascular consequences of adiposity, and is widely used for clinical diagnostic purposes [5]. It has been suggested that polymorphisms in beta 3 adrenoreceptor signal transduction, binding, or regulatory mechanism may result in diminished lipolytic response [33]. In relation to association to $A D R B 3$ methylation profile and body weight the studies are still scarce and this relation needs to be further studied.

Some limitations of the present study are relevant. Regarding the absence of relationship with lipid profile, oxidative stress and food intake, probably did not occured due to the higher prevalence of eutrophic individuals, lower prevalence of obesity from the degree III, and the status of all variables studied situated around 90\% in reference values in the total sample. And as the obeses group was composed mostly by individuals with mild and moderate obesity (grade I e II), there was no representative group of severe obesity (grade III and IV) $(n=5)$ in present study. In addition, a stratification by nutritional status according with gender was not performed, reflecting the methylation levels of the $A D R B 3$ gene in leukocytes based in a representative adult population of both genders.

\section{Conclusions}

In conclusion, it was demonstrated a negative relationship between methylation levels of the $A D R B 3$ gene in individuals eutrophic adults with serum levels of folic acid, as well as with the independent gender of BMI, however, it was not observed relationship between lipid profile, oxidative stress and food intake in individuals distributed in the three categories of BMI.

Regarding the absence of relationship with methylation levels of the $A D R B 3$ gene in the categories of overweight, mild and moderate obesity, the answer probably lies in the insufficient amount of body fat to initiate inflammatory processes and oxidative stress with a direct impact on methylation levels, what differently is found most times in exacerbated levels in severe obesity.

\section{Additional file}

Additional file 1. Additional tables.

\section{Abbreviations}

5-FTHF: 5-formyltetrahydrofolate; 5-MTHF: 5-methyltetrahydrofolate; II DISANDNT/JP: Second Cycle of Diagnosis and Intervention on the Diet, Nutrition and Most Prevalent Noncommunicable Diseases among the Population of João Pessoa, Paraiba; ADRB3: gene encoding beta-3 adrenergic receptor; $\mathrm{AHA}$ : American Heart Association; BMI: body mass index; DHFR: dihydrofolate reductase; HDL: high density lipoprotein; HRM: high resolution melting; LDL: low density lipoprotein; MDA: malondialdehyde; PCR: polymerase chain reaction; PPGCN: Post Graduate Program in Nutrition Sciences; R24h: 24-hour dietary recall; RBC: red blood cells; TAC: total antioxidant capacity; TC: total cholesterol; WC: waist circumference; WHO: World Health Organization; WHR: waist-to-hip ratio; WHtR: waist-to-height ratio; UFPB: Federal University of Paraíba; VAT: visceral adipose tissue.

\section{Authors' contributions}

YdeO contributed to data acquisition and interpretation, and writing of the manuscript. RPAL coordinated the DNA methylation analyses, contributed to data to data management and DNA methylation tests. RCPL, MGAM, CSOdaS and KQFL contributed to data management. NFPdeO was involved in the interpretation and critical review of the manuscript. RPdeTV, FELdeLF and MdaCRG contributed to the analysis of food consumption. ASdaS and RAFdoN contributed to the biochemical analyses. ASD was involved in the development of the manuscript or in the critical review of relevant intellectual content. AHAeS, ATCA and RMdeM contributed to the study design and statistical analysis. MJdeCC contributed to the study design, statistical analysis, data interpretation, and writing of the manuscript; she coordinated data collection and was involved in the development of the manuscript or in the critical review of relevant intellectual content. All authors read and approved the final manuscript.

\section{Author details}

${ }^{1}$ Health Sciences Center (Centro de Ciências da Saúde), Departament of Nutrition, Federal University of Paraíba (Universidade Federal da Paraíba), João Pessoa, Brazil. ${ }^{2}$ Center of Exact Sciences and Nature (Centro de Ciências Exatas e da Natureza), Federal University of Paraíba (Universidade Federal da Paraíba), João Pessoa, Brazil. ${ }^{3}$ Departament of Statistics, Center of Exact Sciences and Nature (Centro de Ciências Exatas e da Natureza), Federal University of Paraíba (Universidade Federal da Paraíba), João Pessoa, Brazil. ${ }^{4}$ Departament of Molecular Biology, Center of Exact Sciences and Nature (Centro de Ciências Exatas e da Natureza), Federal University of Paraíba (Universidade Federal da Paraíba), João Pessoa, Brazil. ${ }^{5}$ Department of Economics, Center for Applied Social Sciences (Centro de Ciências Sociais Aplicadas), Federal University of Paraíba (Universidade Federal da Paraíba), João Pessoa, Brazil. ${ }^{6}$ Departament of Nutrition, Health Sciences Center (Centro de Ciências da Saúde), Federal University of Pernambuco (Universidade Federal de Pernambuco), Recife, Brazil.

\section{Acknowledgements}

We would like to acknowledge the professor Ph.D. José Luiz de Brito Alves (Federal University of Paraíba), who was involved in the critical review of the manuscript. The funding agencies that enabled the project (National Council of Scientific and Technological Development (CNPq), Ministry of Health and Research Support Foundation of the State of Paraíba (FAPESQ, PB, Brazil); and research collaborators (Post Graduate Program in Nutrition Sciences, Federal University of Paraíba). 


\section{Competing interests}

The authors declare that they have no competing interests.

\section{Availability of data and materials}

The data generated in this study are coordinated by Ph.D. Maria José de Carvalho Costa.

\section{Consent for publication}

Not applicable.

\section{Ethics approval and consent to participate}

The study was approved by the Research Ethics Committee of the Center of Health Sciences (CCS), Federal University of Paraíba, under the Protocol Number 0559/13. All subjects gave their written informed consent.

\section{Funding}

The funding agencies that enabled the project (National Council of Scientific and Technological Development (CNPq), Ministry of Health and Research Support Foundation of the State of Paraíba (FAPESQ, PB, Brazil) under the Number EFP_00008187.

\section{Publisher's Note}

Springer Nature remains neutral with regard to jurisdictional claims in published maps and institutional affiliations.

\section{Received: 14 February 2018 Accepted: 28 May 2018}

Published online: 05 June 2018

\section{References}

1. WHO (World Health Organization). Obesity and overweight. Fact sheets. http://www.who.int/news-room/fact-sheets/detail/obesity-and-overw eight. Accessed 20 Nov 2016.

2. NCD Risk Factor Collaboration (NCD-RisC). Trends in adult body-mass index in 200 countries from 1975 to 2014: a pooled analysis of 1698 population-based measurement studies with 19.2 million participants. Lancet. 2016;387(10026):1377-96.

3. Ghosh S, Bouchard C. Convergence between biological, behavioural and genetic determinants of obesity. Nat Rev Genet. 2017;18(12):731-48.

4. Kasinska MA, Drzewoski J, Sliwinska A. Epigenetic modifications in adipose tissue - relation to obesity and diabetes. Arch Med Sci. 2016;12(6):1293-301.

5. Wahl S, Drong A, Lehne B, Loh M, Scott WR, Kunze S, et al. Epigenomewide association study of body mass index, and the adverse outcomes of adiposity. Nature. 2017:541(7635):81-6.

6. Park HJ, Bailey LB, Shade DC, Hausman DB, Hohos NM, Meagher RB, et al. Distinctions in gene-specific changes in DNA methylation in response to folic acid supplementation between women with normal weight and obesity. Obes Res Clin Pract. 2017;11(6):665-76.

7. González-Muniesa P, Mártinez-González MA, Hu FB, Després JP, Matsuzawa Y, Loos RJF, et al. Obes Nat Rev Dis Primers. 2017;3:17034.

8. Crujeiras AB, Diaz-Lagares A, Sandoval J, Milagro FI, Navas-Carretero S, Carreira MC, et al. DNA methylation map in circulating leukocytes mirrors subcutaneous adipose tissue methylation pattern: a genome-wide analysis from non-obese and obese patients. Sci Rep. 2017;7:41903.

9. Kurylowicz A, Jonas M, Lisik W, Jonas M, Wicik ZA, Wierzbicki Z, et al. Obesity is associated with a decrease in expression but not with the hypermethylation of thermogenesis-related genes in adipose tissues. J Transl Med. 2015;13:31.

10. IBGE. Instituto Brasileiro de Geografia e Estatística. Contagem da população 2010. Rio de Janeiro: Ministério do Planejamento; 2010.

11. Kac G, Sichieri R, Gigante DP. Epidemiologia nutricional. Rio de Janeiro: Editora Fiocruz/Editora Atheneu; 2007. p. 580p.

12. Cochran WG. Sampling techniques. 3rd ed. New York: Walter A. Shewhart; 1977. p. 448.

13. Silva AHA, Moraes RM, Costa MJC. Plano amostral utilizando amostragem estratificada juntamente com amostragem sistemática para aplicação do Inquérito nutricional do município de João Pessoa, Paraíba. Disponível em. http://www.de.ufpb.br/ ronei/AnaHerminia2009Escola_Amost ragem2009.pdf. Accessed 20 Mar 2016.

14. World Health Organization. Obesity: preventing and managing the globa epidemic. Report of a WHO consultation, vol. 894. Geneva: World Health Organization; 2000. p. 11-253.

15. Grundy SM, Cleeman J, Daniels SR, Donato KA, Eckel RH, Franklin BA, et al. Diagnosis and management of the metabolic syndrome: an American Heart Association/National Heart, Lung, and Blood Institute scientific statement: executive Summary. Crit Pathw Cardiol. 2005:4(4):198-203.

16. World Health Organization. Definition, diagnostics and classification of diabetes mellitus and its complications. Reports of a WHO consultation. Geneva: World Health Organization; 1999.

17. Ashwell M, Gibson S. Waist-to-height ratio as an indicator of 'early health risk': simpler and more predictive than using a 'matrix' based on BMI and waist circumference. BMJ Open. 2016;6:1-7.

18. Lima RPA, do Nascimento RAF, Luna RCP, Persuhn DC, da Silva AS, da Conceição $M$, et al. Effect of a diet containing folate and hazelnut oil capsule on the methylation level of the ADRB3 gene, lipid profile and oxidative stress in overweight or obese women. Clin Epigenetics. 2017;9:110.

19. R Development Team. R: A language and environment for statistical computing. R foundation for statistical computing. 2009. http://www.r-proje ct.org. Accessed 16 Oct 2017

20. Scaglione F, Panzavolta G. Folate, folic acid and 5-methyltetrahydrofolate are not the same thing. Xenobiotica. 2014;44(5):480-8.

21. Maffetone PB, Rivera-Dominguez I, Laursen PB. Overfat adults and children in developed countries: the public health importance of identifying excess body fat. Front Public Health. 2017:5:190.

22. Fradin D, Boëlle PY, Belot MP, Lachaux F, Tost J, Besse C, et al. Genomewide methylation analysis identifies specific epigenetic marks in severely obese children. Sci Rep. 2017;7:46311

23. Guay SP, Brisson D, Lamarche B, Biron S, Lescelleur O, Biertho L, et al. ADRB3 gene promoter DNA methylation in blood and visceral adipose tissue is associated with metabolic disturbances in men. Epigenomics. 2014;6(1):33-43.

24. Kurokawa N, Young EH, Oka Y, Satoh H, Wareham NJ, Sandhu MS, et al. The ADRB3 Trp64Arg variant and BMI: a meta-analysis of 44,833 individuals. Int J Obes (Lond). 2008;32(8):1240-9.

25. Reinius LE, Acevedo N, Joerink M, Pershagen G, Dahlen SE, Greco D, et al. Differential DNA methylation in purified human blood cells: implications for cell lineage and studies on disease susceptibility. PLOS ONE. 2012;7:e41361

26. Costa LA, da Silva ICB, Mariz BALA, da Silva MB, Freitas-Ribeiro GM, de Oliveira NFP. Influence of smoking on methylation and hydroxymethylation levels in global DNA and specific sites of KRT14, KRT19, MIR-9-3 and MIR-137 genes of oral mucosa. Arch Oral Biol. 2016;72:56-65.

27. Bendre M, Comasco E, Checknita D, Tiihonen J, Hodgins S, Nilsson KW. Associations between MAOA-uVNTR genotype, maltreatment, MAOA methylation and alcohol consumption in young adult males. Alcohol Clin Exp Res. 2018:42(3):508-19.

28. Callahan CL, Bonner MR, Nie J, Han D, Wang Y, Tao MH, et al. Lifetime exposure to ambient air pollution and methylation of tumor suppressor genes in breast tumors. Environ Res. 2018;161:418-24.

29. Da Silva Melo AR, Barroso H, Uchôa De Araújo D, Ruidomar Pereira F, De Oliveira NF. The influence of sun exposure on the DNA methylation status of MMP9, miR-137, KRT14 and KRT19 genes in human skin. Eur J Dermatol. 2015;25(5):436-43.

30. Li X, Lu J, Teng W, Zhao C, Ye X. Quantitative evaluation of MMP-9 and TIMP-1 promoter methylation in chronic periodontitis. DNA Cell Biol. 2018. https://doi.org/10.1089/dna.2017.3948.

31. Edwards M, Dai R, Ahmed SA. Our environment shapes Us: the importance of environment and sex differences in regulation of autoantibody production. Front Immunol. 2018:9:478.

32. Li S, Zhang J, Huang S, He X. Genome-wide analysis reveals that exon methylation facilitates its selective usage in the human transcriptome. Brief Bioinform. 2017. https://doi.org/10.1093/bib/bbx019.

33. De Luis Román DA, Primo D, Izaola O, Aller R. Relation of Trp64Arg polymorphism of beta 3 adrenoreceptor gene with metabolic syndrome and insulin resistance in obese women. Nutr Hosp. 2017;34(2):383-8. 